\title{
Pengaruh Penambahan Agar-Agar Sebagai Bahan Pengental dengan Konsentrasi Yang Berbeda Terhadap Kualitas Daya Leleh dan Nilai Organoleptik Es Krim
}

\author{
Effect of Adding Agar As A Thickening With Different Concentration on The Quality of \\ Melting Power and Organoleptic Value In Ice Cream
}

\section{Arifin Amrullah *, Intan Dwi Novieta, Rasbawati}

\author{
Program Studi Peternakan, Fakultas Pertanian, Peternakan dan Perikanan, Universitas \\ Muhammadiyah Parepare, 91132, Sulawesi Selatan, Indonesia \\ *Korespondensi E-mail: amrullaharifin97@gmail.com
}

\begin{abstract}
ABSTRAK
Penelitian ini bertujuan untuk mengetahui pengaruh penambahan agar-agar sebagai bahan pengental pada konsentrasi yang berbeda terhadap daya leleh dan nilai organoleptik es krim. Hasil penelitian menunjukkan bahwa Pengaruh penambahan agar-agar sebagai bahan pengental dengan konsentrasi yang berbeda terhadap kualitas daya leleh dan nilai organoleptik pada es krim, memberikan pengaruh yang sangat nyata. Rata-rata daya leleh tertinggi keterendah yaitu P3 sebesar (28,53 menit), P2 sebesar (20,05 menit), P1 sebesar (13,58 menit), dan P0 sebesar (10,40 menit). Hasil nilai uji organoleptik yaitu untuk karateristik tekstur yang paling lembut diperoleh P3 dengan rerata skor $(4,4)$, karateristik warna yang sangat merah diperoleh P3 dengan rerata skor $(4,69)$, karateristik aroma susu dan agar-agar diperoleh P3 dengan rerata skor $(4,21)$, karateristik rasa yang paling manis diperoleh P3 dengan rerata skor $(4,77)$. Dari kesimpulan hasil penelitian maka diketahui bahwa perlakuan terbaik yang dapat direkomendasikan yaitu perlakuan P3 untuk daya leleh dan nilai organoleptik es krim.
\end{abstract}

Kata Kunci: Es Krim, Agar-Agar, Organoleptik, Daya Leleh.

\begin{abstract}
This study aims to determine the effect of adding jelly as a thickening with different concentrations on the quality of melting and the organoleptic in ice cream.The results showed that the effect of adding jelly as a thickening with different concentrations on the quality of melting and the organoleptic in ice cream had a very real effect. The highest average melting power to the lowest; P3 is (28.53 minutes), P2 is (20.05minutes), P1 is (13.58minutes) and P0 is (10.40minutes). The results of organoleptic test values are for the softest characteristics obtained P3 with an average score (4.4), very red color characteristics obtained P3 with an average score (6.49), Characteristics of milk aroma and jelly obtained by P3 with an
\end{abstract}


average score $(4,21)$, and the sweetest taste characteristic is obtained P3 with an average score (4.77). From the conclusion results of the study it is known that the best treatment that can be recommended is the P3 treatment for melting power and the organoleptic value of ice cream.

Keywords: Ice Cream, Agar, Organoleptic, Melting Power.

\section{PENDAHULUAN}

Es krim merupakan salah satu makanan penutup yang digemari di seluruh dunia.Es krim mempunyai rasa yang lezat, aromanya harum, warnanya menarik, dan teksturnya yang lembut.Es krim merupakan jenis makanan yang bernilai gizi tinggi yaitu mengandung protein, lemak, karbohidrat, vitamin dan mineral. Kandungan lemak dalam es krim tiga sampai empat kali lebih banyak dari pada susu dan setengah dari total padatnya berupa gula, oleh karena itu es krim dapat digunakan untuk menambah berat badan dan untuk membantu pertumbuhan anak. Menurut Standar Nasional Indonesia (SNI 01-3713-1995) es krim didefinisikan sebagai makanan semi padat yang dibuat dengan cara pembekuan campuran susu lemak hewani maupun nabati, gula dengan atau tanpa bahan makanan lain dan bahan makanan yang diizinkan.

Rumput laut menghasilkan beberapa polisakarida sebagai contoh adalah alginat yang berasal dari alga coklat. Menurut Rehm (2009), alginat adalah polisakarida yang merupakan struktur komponen dari alga (Phaeophyceae), dimana terdapat lebih dari $40 \%$ bahan kering terdapat di dalam getah intraselular dan dinding sel alga yang tidak dapat larut dalam kalsium, magnesium, potassium dan garam sodium. Kegunaan dari alginat sangat beragam dapat diaplikasikan untuk penstabil, pengemulsi bahan makanan.

Kelemahan pada proses pembuatan es krim yang sering timbul adalah kecepatan meleleh yang relatif cepat, oleh karena itu perlu adanya usaha untuk mencapai kondisi kecepatan leleh yang sesuai dengan kualitas es krim yaitu dengan menambahkan stabilizer. Fungsi daristabilizer adalah sebagai pengemulsi yaitu pengikatan globula yang berasal dari molekul lemak, air dan udara. Dengan 
demikian dapat mencegah terbentuknya kristal es yang lebih besar, memberikan tekstur yang lembut dan mempertahankan pelelehan es krim pada saat dihidangkan, serta berpengaruh terhadap "overrun" (Eckles et al., 1984).Sehubungan hal tersebut diatas maka akan dilakukan penelitian tentang Pengaruh Penambahan Agar-Agar Sebagai Bahan Pengental Dengan Konsentrasi Yang Berbeda Terhadap Kualitas Daya Leleh Dan Nilai Organoleptik Pada Es Krim.

\section{METODE}

Metode penelitian eksperimental menggunakan Rancangan Acak Lengkap (RAL), 4 kombinasi perlakuan dengan 3 kali ulangan, perlakuan terdiri atas: P0 : Kontrol ( tanpa penambahan agar-agar), P1 : 5 \%agar-agar, P2: 10 \% agar-agar, P3 : $15 \%$ agar-agar.

\section{Pembuatan Es krim}

Langkah-langkah pembuatan es krim adalah melarutkan maizena kemudian disisihkan, mencampurkan susu kental manis (6 sachet), gula (15 sendok), air (1500 cc), agar-agar (dengan konsentrasi $5 \%, 10 \%$ dan $15 \%$ ) dan tambahkan tepung maizena ( 3 sendok) kemudian aduk menggunakan mixer hingga tercampur rata. memasukan maizena sambil diaduk, didikan kembali sambil terus diaduk kemudian angkat dan biarkan dingin, mendiamkan selama 10 menit, lalu memasukan ke dalam freezer, tunggu selama 15 menit, kemudian aduk kembali menggunakan mixer, terakhir pengemasan dalam cup cream dan disimpandalam freezer selama 8 jam agar es krim dapat membeku sempurna.

\section{Analisis Data}

Data yang diperoleh dari panelitian ini dianalisis dengan menggunakan rancangan acak lengkap (RAL). Apabila perlakuan berpengaruh nyata dilanjutkan dengan uji jarak berganda duncan, data dianalisis dengan bantuan program SPSS.

\section{HASIL DAN PEMBAHASAN}

\section{Daya Leleh Es Krim}


Berdasarkan hasil penelitian uji daya leleh es krim pada penambahan agaragar sebagai bahan pengental dengan konsentrasi yang berbeda dapat dilihat pada Tabel 1 berikut.

Tabel 1. Nilai uji daya leleh es krim dengan bahan pengental agar-agar dengan konsentrasi yang berbeda, superkrip yang berbeda pada gambar menunjukkan berpengaruh sangat nyata $(\mathrm{P}<0,01)$.

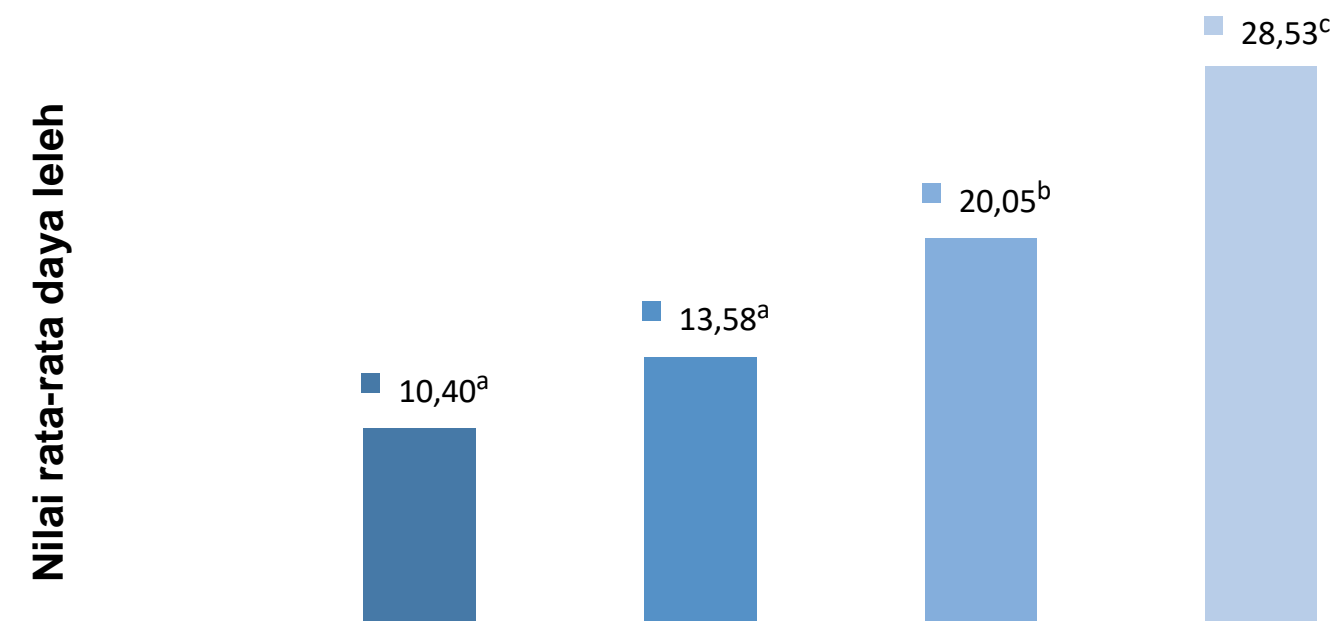

Perlakuan

Berdasarkan analisis ragam diketahui bahwa perlakuan bahan pengental yang berbeda berpengaruh sangat nyata $(\mathrm{P}<0,01)$ terhadap daya leleh es krim dan setelah dilanjutkan uji Duncan terdapat perbedaan yang nyata. Perlakuan P0 berbeda nyata dengan perlakuan P2 dan P3 namun tidak berbeda nyata dengan P1.Perlakuan P1 berbeda nyata dengan P2dan P3 namun tidak berbeda nyata dengan P0. Perlakuan P2 berbeda nyata dengan perlakuan P0, P2dan P3 dan Perlakuan P3 berbeda nyata dengan P0, P1dan P2.

Berdasarkan analisis ragam diketahui bahwa perlakuan bahan pengental yang berbedaberpengaruh sangat nyata $(\mathrm{P}<0,01)$ terhadap kandungan daya leleh es krim. Pada hasil analisis Duncan terdapat perbedaan nyata antara perlakuan P0 dan P1 dengan perlakuan P2, P3 dan P0 tidak berbeda nyata dengan perlakuan P1. Adapun hasil yang terbaik waktu daya leleh es krim adalah pada perlakuan P2 (10 \% agar- 
agar) menunjukan waktu meleleh 20.05 menit dan P3 (15\% agar-agar)menunjukan waktu meleleh lebih lama 30,22 menit dibandingkan dengan perlakuan P0 (kontrol) es krim tanpapenambahanagar-agarmemilikiwaktumelelehpalingcepat10,40menit dan P1 (5 \% agar-agar) memiliki waktu meleleh 13.58 menit.

Penambahan bahan pengental pada es krim dapat meningkatkan kualitas daya leleh es krim.Semakin tinggi konsentrasi bahan pengental agar-agar maka akan meningkatkan kualitas daya leleh es krim. Hal ini sesuai dengan pendapat Goff(2000) bahwa Salah satu bahan yang sangat berpengaruh terhadap waktu leleh adalah jenis dan konsentrasi bahan penstabil. Bahan penstabil dapat mencegah pelelehan yang berlebih, bertanggung jawab terhadap bentuk body, kelembutan dan kesegaran. Hal ini karena semakin banyak konsentrasi penstabil yang ditambahkan maka akan mengakibatkan terjadi peningkatan jumlah air bebas yang terperangkap sehingga akan menghasilkan es krim yang lebih tahan dan memiliki waktu leleh paling lama (Hartel, 2004).

Pada perlakuan P2 dan P3 waktu daya leleh berkisar antara 20.05 dan 28.53 menit termasuk dalam kisaran daya leleh yang baik hal ini sesuai dengan pendapat Goff dan Hartel (2013) yang menyatakan bahwa kisaran pelelehan yang baik pada es krim adalah sekitar 15-20 menit pada suhu ruang dan menurut Akesowan,(2008) bahwa es krim yang baik mempunyai kecepatan meleleh antara 20 - 30 menit/100 gram (1200-1800 detik/100 gram bahan) pada suhu kamar. Daya leleh es krim dapatdipengaruhi oleh bahan baku pembuatan es krim seperti protein, padatandan bahan penstabil. Kecepatan daya leleh dipengaruhi oleh bahan-bahan yang digunakan dalam pembuatan es krim dan besarnya persentase overrun yang dihasilkan.

\section{Tekstur Es Krim}

Berdasarkan hasil penelitian uji organoleptik tekstur es krim pada penambahan agar-agar sebagai bahan pengental dengan konsentrasi yang berbeda dapat dilihat pada Tabel 2 berikut: 
Tabel 2. Nilai Uji Organoleptik Tekstur Es Krim dengan Bahan Pengental Dengan Konsentrasi yang Berbeda, Superkrip yang Berbeda Pada Grafik Menunjukkan Berpengaruh Sangat Nyata $(P<0,01)$.

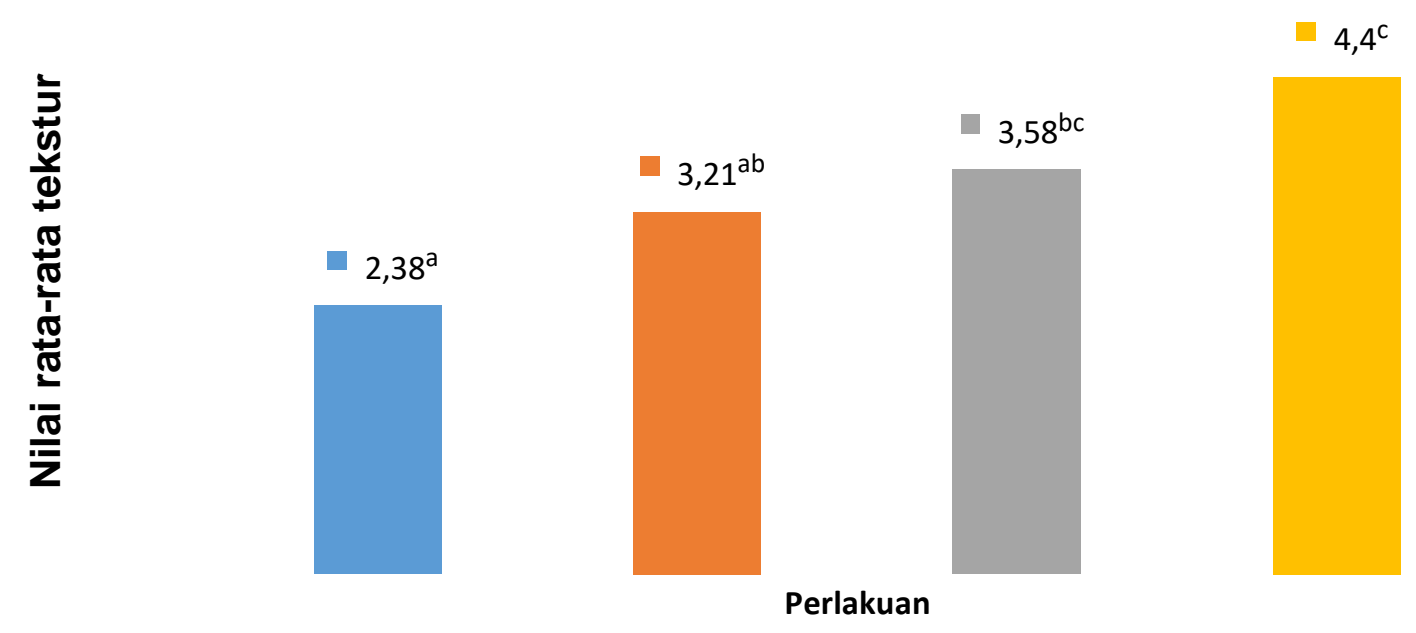

Berdasarkan analisis ragam diketahui bahwa perlakuan bahan pengental yang berbeda berpengaruh sangat nyata $(P<0,01)$ terhadap tekstur es krim dan setelah dilanjutkan uji Duncan terdapat perbedaan yang nyata. Perlakuan P0 berbeda nyata dengan perlakuan P2 dan P3 namun tidak berbeda nyata dengan P1.Perlakuan P1 berbeda nyata dengan P2dan P3 namun tidak berbeda nyata dengan P0. Perlakuan P2 berbeda nyata dengan perlakuan P0, P2dan P3 dan Perlakuan P3 berbeda nyata dengan P0, P1dan P2.

Hasil analisis ragam menunjukkan bahwa perlakuan penambahan agar-agar sebagai bahan pengental dengan konsentrasi yang berbeda berpengaruh sangat nyata $(\mathrm{P}<0,01)$ terhadap tekstur es krim. Pada hasil uji lanjut Duncan menunjukan perbedaan nyata pada perlakuan P0 (kontrol) dengan P2 (10\% agar-agar) dan P3 (15 \% agar-agar).Namun tidak terjadi perbedaan nyata antara P0 (kontrol) dengan P1 (5 \% agar-agar).Pada konsentrasi penambahan P2 (10\% agar-agar) dan P3 (15\% agaragar) memiliki tekstur yang lembut dan Padaperlakuan P0 (kontrol) dan P1 (5 \% agar-agar) tekstur es krim sedikit lembut.

Penambahan bahan pengental pada es krim dapat meningkatkan kualitas tekstur es krim.Es krim pada perlakuan P2 dan P3 memiliki tekstur yang lebih 
lembut dibandingkan dengan es krim pada perlakuan P0 dan P1.Semakin tinggi persentase penambahan agar-agar, maka tekstur yang terdeteksi semakin lembut.Tekstures krim yang baik adalah halus dan lembut hal ini sesuai dengan pendapatPadaga et al., (2005) yang menyatakan bahwa tekstur es krim yang baik adalah halus dan lembut (smooth), tidak keras dan tampak mengkilat sedangkan yang buruk adalah adanya rasa gumpalan lemak (greasy), terasa seperti tepung (grainy), terasa adanya serpihan es (flak atausnowy) dan berpasir (sandy). Teksturdipengaruhi oleh beberapa faktor yaitu komposisi es krim mix, cara pengolahan, kondisi penyimpanan, kristal es, globula lemak, gelembung udara dan kristal laktosa hal ini sesuai dengan pendapat Padaga (2005) bahwa tekstur lembut es krim sangat dipengaruhi oleh komposisi ICM, cara mengolah dan kondisi penyimpanan.

Pengembangan volume adonan es krim menjadikan es krim lebih ringan dan tidak terlalu padat serta mempunyai tekstur yang lembut.Produkes krim ditentukan oleh padatan dalam adonan, konsentrasi gula dan kekentalan.Gula akan menghalangi pembekuan produk, karena molekul gula akan menarik molekul air sehingga mengganggu pembentukan kristal-kristal es. Gula dapat membantu mencegah pembentukan kristal es yang besar, sehingga tekstur yang dihasilkan lebih lembut (Clarke, 2004).Faktor lain yang mempengaruhi tekstur es krim adalah penambahan bahan penstabil dan pengemulsi (Aime et al. 2001).

Pada penelitian ini perlakuan tanpa penambahanbahan pengental, tekstur es krim yang dihasilkan akan menjadi kasar karena terbentuk kristal-kristal es dibandingkan dengan perlakuan dengan penambahan agar-agar sebagai bahan pengental. Berdasarkan standart penggunaan konsentrasi stabilizer yang sudah ditetapkan dalam komposisi ICM dalam pembuatan es krim berkisar pada 0,2\%0,5\%. Menurut Arbuckle (1997), tujuan utama penggunaan bahan penstabil pada es krim adalah untuk menghasilkan kehalusan dan tekstur yang baik, untuk menghambat atau mengurangi pembentukan kembali kristal es krim selama penyimpanan, menghasilkan keseragaman produk, dan menghambat pelelehan. 
Bahan penstabil atau stabilizer yang merupakan senyawa-senyawa hidrokoloid, biasanya polisakarida, yang berperan dalam meningkatkan kekentalan Ice CreamMix (ICM) terutama pada keadaan sebelum dibekukan.Rumput laut adalah penghasil bahan-bahan hidrokoloid yang merupakan produk dasar.Senyawa hidro-koloid pada rumput laut sangat diperlukan keberadaannya dalam suatu produk karena berfungsi sebagai pembentuk gel, penstabil, pengemulsi, pensuspensi, pengikat, pengental dan pendispersi.

\section{Warna Es Krim}

Berdasarkan hasil penelitian uji organoleptik warna es krim pada penambahan agar-agar sebagai bahan pengental dengan konsentrasi yang berbeda dapat dilihat pada Tabel 3 berikut;

Tabel 3. Nilai Uji Organoleptik Warna Es Krim Dengan Bahan Pengental dengan Konsentrasi yang Berbeda, Superkrip yang Berbeda pada Grafik Menunjukkan Berpengaruh Sangat Nyata $(\mathrm{P}<0,01)$.

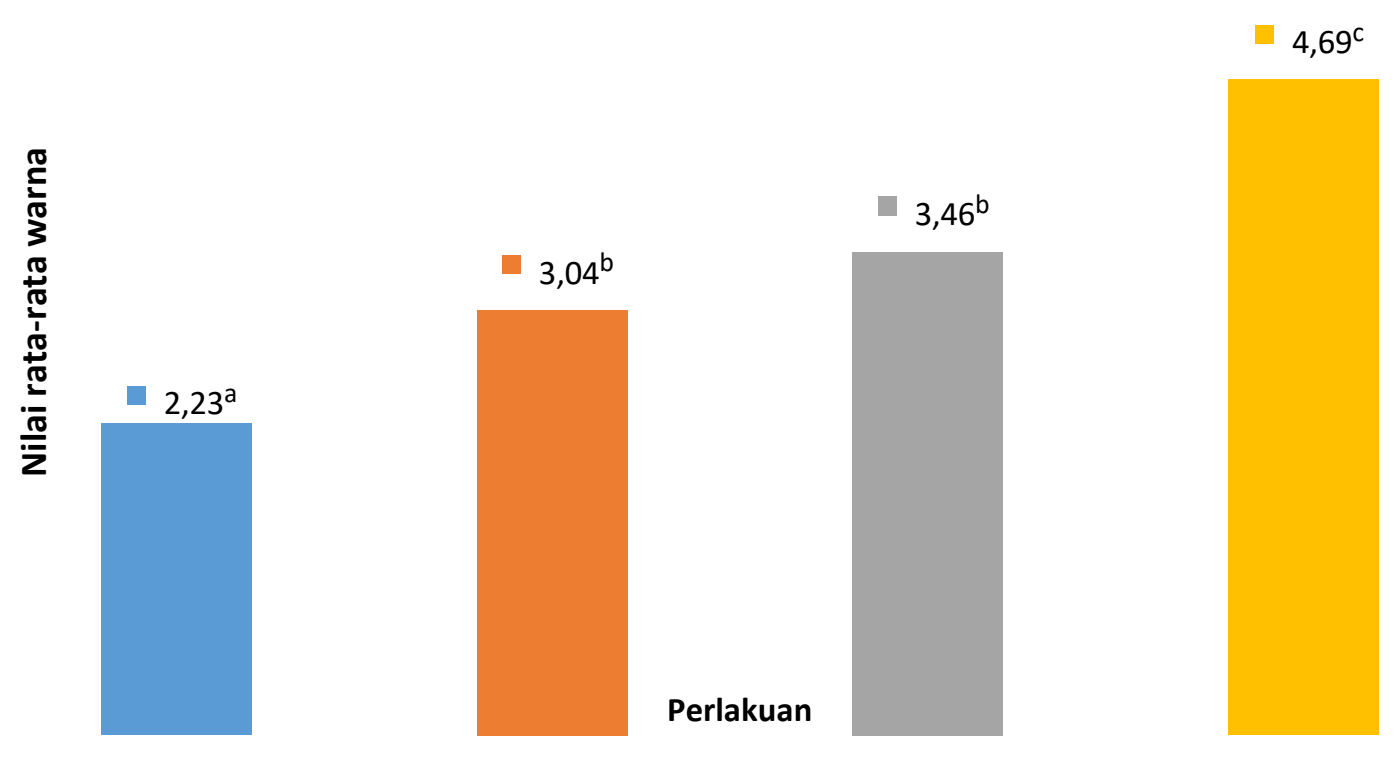

Berdasarkan analisis ragam diketahui bahwa perlakuan bahan pengental yang berbeda berpengaruh sangat nyata $(\mathrm{P}<0,01)$ terhadap warna es dan setelah dilanjutkan uji Duncan terdapat perbedaan yang nyata.PerlakuanP0 berbeda nyata 
dengan perlakuan P1, P2 danP3. Perlakuan P1 berbeda nyata dengan P0 dan P3 namun tidak berbeda nyata dengan P2.Perlakuan P2 berbeda nyata dengan P0dan P3 namun tidak berbeda nyata dengan P1. Perlakuan P3 berbeda nyata dengan perlakuan P0, P1 dan P2.

Hasil analisis ragam menunjukkan bahwa perlakuan penambahan agar-agar sebagai bahan pengental dengan konsentrasi yang berbeda berpengaruh sangat nyata $(\mathrm{P}<0,01)$ terhadap warna es krim. Pada Pada hasil uji lanjut Duncan menunjukan perbedaan nyata pada perlakuan P0 (kontrol) dengan P1 (5 \% agaragar), P2 (10 \% agar-agar) dan P3 (15\% agar-agar) namun tidak terjadi perbedaan nyata antara P1 (5 \% agar-agar) dengan P2 (10\% agar-agar). Pada perlakuan P0 (kontrol) warna es krim sedikit merah sedangkan pada perlakuan P2 (10\% agaragar) dan P3 (15\% agar-agar) memiliki warna merah dan pada perlakuan P1 (5\% agar-agar) dan P2 (10\% agar-agar) warna es krim agak merah.

Penambahan bahan pengental pada es krim dapat meningkatkan kualitas warna es krim.Es krim tanpa penambahan agar-agar memiliki warna yang sedikit merah dibandingkan dengan es krim dengan penambahan agar-agar yang memiliki warna merah.Warna merah pada es krim berasal dari bahan pengental agar-agar. Kasein susu memiliki sifat tidak tembus cahaya, sehingga semua gelombang cahaya direfleksikan dan membentuk warna merah. Tingkat kemerahan warna es krim cenderung meningkat seiring dengan penambahan presentase bahan pengental.Hal ini terjadi karena adanya penggunaan agar-agar yang berfungsi sebagai pemberi warna pada es krim. Hal ini sesuai dengan pendapat (Dawes, 1981) yang menyatakan bahwarhodophyta adalah alga berwarna merah.

Warna merah pada rhodophyta dikarenakan oleh cadangan fikorietrin yang lebih dominan, dibanding pigmen lain. rhodophyta juga memiliki pigmen lain yaitu klorofil, karotenoid dan pada jenis tertentu terdapat fikosianindan di dukung oleh pendapat Muchtadi (1989), bahwa warna bahan pangan dapat dipengaruhi oleh beberapa sumber seperti adanya pigmen dalam tanaman dan hewan, pengaruh panas pada gula, reaksi kimia antara gula dengan asam amino, kontak asam organik 
dengan udara, serta penambahan zat pewarna alami dan sintetis. Warna yang diharapkan pada es krimsesuai bahan pengental agar-agar adalah warna merah.

\section{Aroma Es Krim}

Berdasarkan hasil penelitian uji organoleptik aroma es krim pada penambahan agar-agar sebagai bahan pengental dengan konsentrasi yang berbeda dapat dilihat pada Tabel 4 berikut:

Tabel 4. Nilai uji organoleptik aroma es krim dengan bahan pengental dengan konsentrasi yang berbeda, superkrip yang berbeda pada grafik yang menunjukkan berpengaruh sangat nyata $(\mathrm{P}<0,01)$.

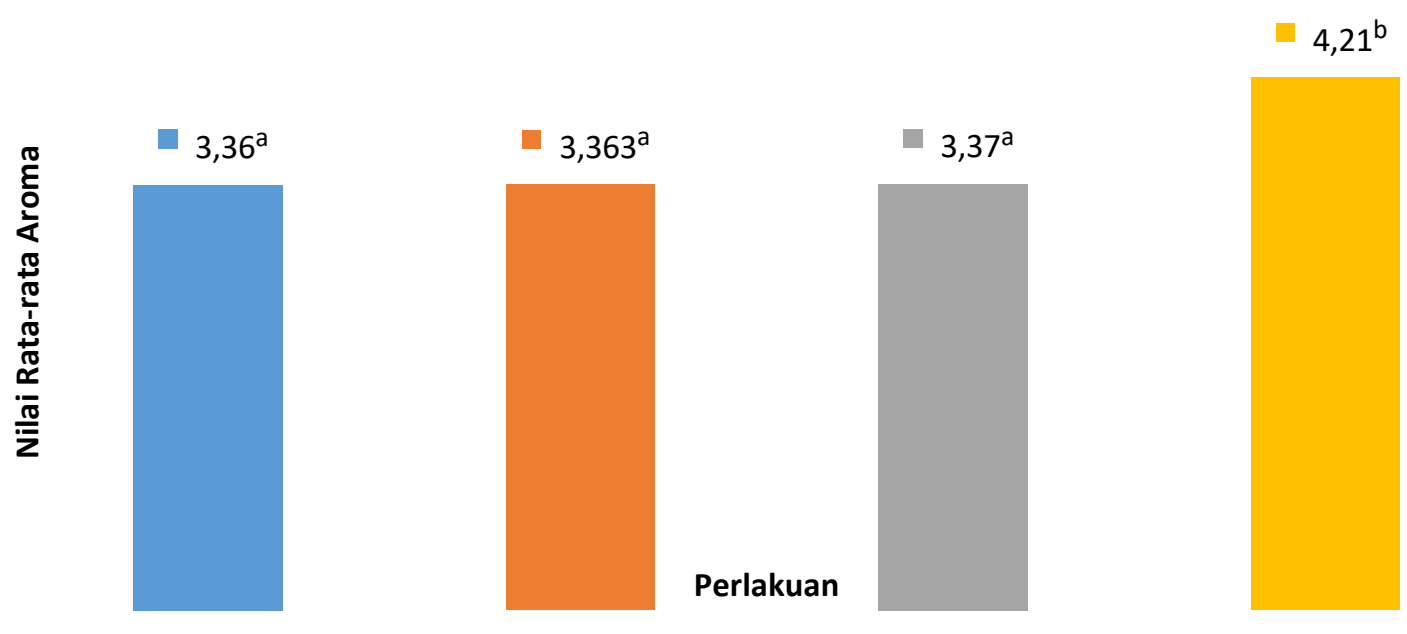

Berdasarkan analisis ragam diketahui bahwa perlakuan bahan pengental yang berbeda berpengaruh sangat nyata $(\mathrm{P}<0,01)$ terhadap aroma es krim dan setelah dilanjutkan uji Duncan terdapat perbedaan yang nyata. Perlakuan PO berbeda nyata dengan P3 namun tidak berbeda nyata dengan P1dan P2. Perlakuan P1 berbeda nyata dengan P3 namun tidak berbeda nyata dengan P0dan P2. Perlakuan P2 berbeda nyata dengan P3 namun tidak berbeda nyata dengan P0dan P2. perlakuan P3 berbeda nyata dengan perlakuan P0, P1dan P2.

Hasil analisis ragam menunjukkan bahwa perlakuan penambahan agar-agar sebagai bahan pengental dengan konsentrasi yang berbeda berpengaruh sangat nyata $(\mathrm{P}<0,01)$ terhadap aroma es krim. Pada hasil uji lanjut Duncan menunjukan perbedaan nyata pada perlakuan P0 (kontrol), P1 (5 \% agar-agar) P2 (10\% agar-agar) berbeda nyata dengan P3 (15\% agar-agar) namun P0 (kontrol) tidak terjadi 
perbedaan nyata antara P1 (5 \% agar-agar) dengan P2 (10 \% agar-agar).Pada perlakuan P0 (kontrol), P1 (5 \% agar-agar) dan P2 (10\% agar-agar) es krim agak beraroma agar-agar sedangkan pada perlakuan dan P3 (15\% agar-agar) es krim beraroma agar-agar. Menurut Suryani (2006), bahwa aroma es krim yang dihasilkan dari aroma khas susu serta bahan tambah yang ditambahkan, sehingga mempengaruhi aroma yang dihasilkan.

Penambahan bahan pengental pada es krim dapat meningkatkan kualitas aroma es krim dengan konsentrasipenggunaan bahan pengentaltertentu.Aroma pada suatu bahan pangan atau produk dipengaruhi oleh bahan tambahan yang digunakan seperti penguat cita rasa, Hal ini sesuai dengan pendapat Afrianti (2008), bahwa penguat cita rasa adalah suatu zat bahan tambahan yang ditambahkan kedalam makanan yang dapat memperkuat aroma dan rasa. Pendapat Mahawan (2012), aroma pada es krim yang dihasilkan dipengaruhi oleh bahan subtitusi yang digunakan, aroma pada suatu bahan pangan akan dipengaruhi oleh bahan tambah yang digunakan seperti penguat cita rasa, tetapi jika penambahan berlebihan akan mengurangi aroma es krim itu sendiri.

Pada penelitian ini menunjukkan bahwa perlakuan P3berbeda nyata terhadap es krim yang dihasilkan namuntidak berbeda nyata pada perlakuan P0, P1 dan P2.Hal ini disebabkan karena adanya aroma tambahan yang terdapat pada es krim.Semakin tinggi penambahan agar-agar sebagai bahan pengental,maka aroma es krim menjadi semakin beraroma agar-agar namun aroma juga dipengaruhioleh bahan tambahan yang digunakan.Aroma pada suatu bahan pangan atau produk dipengaruhi oleh bahan tambahan yang digunakan seperti penguat cita rasa, Hal ini sesuai dengan pendapat Afrianti (2008), bahwa penguat cita rasa adalah suatu zat bahan tambahan yang ditambahkan kedalammakanan yang dapat memperkuat aroma dan rasa.Menurut Suryani (2006), bahwa aroma es krim yang dihasilkan dari aroma khas susu serta bahan tambahyang ditambahkan, sehingga mempengaruhi aroma yang dihasilkan.

\section{Rasa Es Krim}


Berdasarkan hasil penelitian uji organoleptik rasa es krim pada penambahan agar-agar sebagai bahan pengental dengan konsentrasi yang berbeda dapat dilihat pada Tabel 5 berikut:

Tabel 5. Nilai Uji Organoleptik Rasa Es Krim dengan Bahan Pengental dengan Konsentrasi yang Berbeda, Superkrip yang Berbeda pada Grafik Menunjukkan Berpengaruh Sangat Nyata $(P<0,01)$.
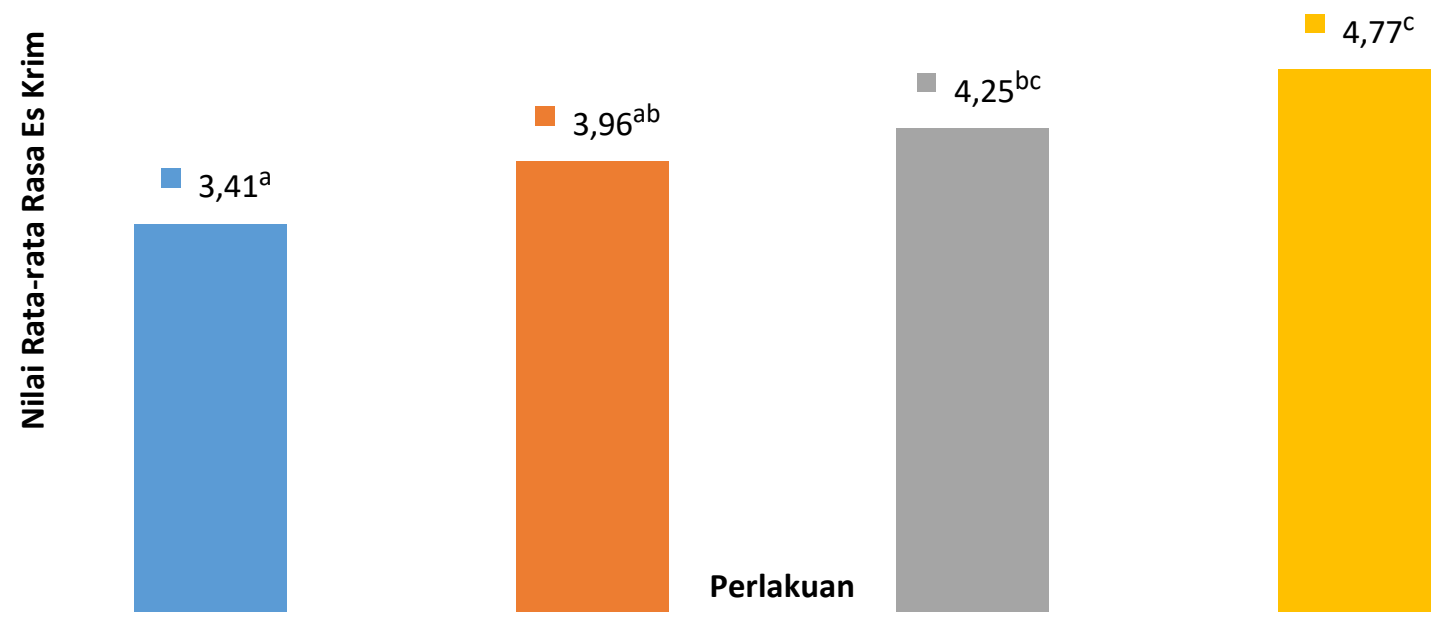

Berdasarkan analisis ragam diketahui bahwa perlakuan bahan pengental yang berbedaberpengaruh sangat nyata $(\mathrm{P}<0,01)$ terhadap rasa es krim dan setelah dilanjutkan uji Duncan terdapat perbedaan yang nyata. Perlakuan P0 berbeda nyata dengan perlakuan P2 dan P3 namun tidak berbeda nyata dengan P1.Perlakuan P1 berbeda nyata dengan P2,dan P3 namun tidak berbeda nyata dengan P0. Perlakuan P2 berbeda nyata dengan perlakuan P0, P2dan P3 dan Perlakuan P3 berbeda nyata dengan P0, P1dan P2.

Hasil analisis ragam menunjukkan bahwa perlakuan penambahan agar-agar sebagai bahan pengental dengan konsentrasi yang berbedatidak berpengaruh sangat nyata $(\mathrm{P}<0,01)$ terhadap rasa es krim. Pada hasil uji lanjut Duncan menunjukan perbedaan nyata pada perlakuan P0 (kontrol) dengan P2 (10\% agar-agar) dan P3 (15 \% agar-agar) namun tidak terjadi perbedaan antara P0 (kontrol) dengan P1 (5 \% 
agar-agar). Pada perlakuan P2 (10\% agar-agar) dan P3 (15\% agar-agar) es krim memiliki rasa yang manis dan Pada perlakuan P0 (kontrol) dan P1 (5 \% agar-agar) es krim memiliki rasa yang agak manis

Penambahan bahan pengental pada es krim dapat meningkatkan kualitas rasa pada es krim dengan konsentrasitertentu pada penggunaan bahan pengental agaragartetapi rasa yang dominan pada penelitiian ini adalah rasa manis yang timbul akibat susu kental manis dan penambahan gula. Hal ini sesuai dengan pendapat (Thompson et al.,2009) yang menyatakan bahwarasa sangat mempengaruhi kesukaan konsumen terhadap es krim bahkan dapat dikatakan faktor penentu utama. Bahan pengental dapat mengurangi rasa manis gula dan mengubah cita rasa es krim. Penggunaan agar-agar sebagai bahan pengental tidak terlalu berpengaruh pada rasa eskrim.Hal ini diduga karena salah satu karakteristik rumput laut adalah tidak berasa atau netral.

Rasa yang dihasilkan dari produk es krim tersebut masih mencirikan bahwa bahan utama (susu) dan rasa yang dominan adalah rasa manis yang timbul akibat susu kental manis dan penambahan gula (Astawan, 2008). Rasa pada es krim sangat dipengaruhi oleh bahan-bahan penyusun ICM yaitu susu, whipping, susu skim, agar-agar, dan gula pasir. Sehingga es krim yang dihasilkan rata-rata disukai oleh panelis karena kombinasi dari bahan-bahan penyusun ICM tersebut. Hal ini sesuai dengan pendapat Padaga, M, $d k k$, (2005), bahwa es krim adalah produk pangan beku yang dibuat melalui kombinasi proses pembekuan dan agitasi pada bahan-bahan yang terdiri dari susu dan produk susu, pemanis, penstabil, pengemulsi serta penambah cita rasa(flavor).

\section{KESIMPULAN}

Berdasarkan hasil dan pembahasan maka dapat ditarik kesimpulan bahwa perlakuan penambahan agar-agar sebagai bahan pengental dengan konsentrasi yang berbeda dapat mempengaruhi daya leleh es krim dan nilai organoleptik es krim, adapun perlakuan terbaik adalah perlakuan P3 (15\% agar-agar)dengan daya leleh 30,22 menit dan perlakuan P2 (10 \% agar-agar) dengan daya leleh 20.05 menit dan perlakuanterbaik nilai organoleptik tekstur, warna, aroma dan rasa es krim ada pada perlakuan P3. 


\section{DAFTAR PUSTAKA}

Afrianti, L.H., 2008. Teknologi Pengawetan Pangan. Alfabeta, Bandung.

Aime, D. B. Et al. Textural analysis of fat reduced vanilla ice cream products. Food Research International, 34: 237-246.

Akesowan, A. 2008.Effect of combined stabilizers containing konjac flour and Kcarrageenan on ice cream.AU Journal of Thailand, 12 (2): 81-85. 30

Arbuckle, W.S. 1997. Ice Cream 5th Edition. New York: The AVI Publishing Company.

Clarke, C. 2004. The Science of Ice Cream.The Royal Society of Chemistry, Thomas Graham House. Milton Road, Cambridge (UK).

Dawes, C.J. 1981. Marine Botany.Jhon Wiley dan Sons, Inc. New York. Pp: 25- 230

Eckles, E.H., Combs,W.B., and Macy, H. 1984. Milk and Milk Products. McGrawHill Book Co. Inc., New York.

Goff, H.D., and Hartel, R.W. 2013. Ice Cream Seventh Edition. New York: Springer

Goff, H.D. 2000. Controlling Ice Cream Structure by Examining Fat Protein Interactions. J. Dairy Technology.

Mahawan, A. 2012. Pemanfaatan Umbi Ubi Jalar Ungu Sebagai Bahan Baku Pembuatan Es Krim. Jurnal Pendidikan Teknologi Pertanian, 4. 2018

Muchtadi, D. dan Sugiyono, T.R. 1989. Petunjuk Laboratorium Ilmu Pengetahuan Bahan Pangan. Departemen Pendidikan dan Kebudayaan.Direktorat Jendral Pendidikan Tinggi PAU Pangan dan Gizi. IPB, Bogor.

Padaga, M dan Sawitri. M.E. 2005. Membuat Es Krim yang Sehat. Trubus Agrisarana, Surabaya.

Rehm, B.H.A. 2009. Alginates: Biology and Dordrecht Heidelberg. 21. Applications.

Suryani, T. D. Pengaruh Tingkat Penggunaan Starter Yoghurt Terhadap Overrun, Kecepatan Meleleh, dan Mutu Organoleptik Ice Cream. Skripsi. Fakultas Peternakan-Universitas Brawijaya. Malang.

Thompson, K. R,. D. H. Chambers, anal E. Chambers. 2009. Sensory characteristic of ice cream produced in the Unileal States and Italy. Published In Jourhal of Sensory Studies, 24 : 396-414 